\section{Keeping Tabs on U.S.} Policymakers

An invisible boundary seems to separate those who participate in Washington politics and policy and those who don't. Step across that boundary and one enters what can seem like an ephemeral world of committees, subcommittees, and working groups. Just as one begins to make sense of it all, a new Administration or a shift in Congress throws it in limbo again. So it seems.

Actually, names may change and committees may dissolve, but policies can continue to flourish. At least that's how Lyle H. Schwartz, director of materials science and engineering at the National Institute of Standards and Technology in Gaithersburg, Maryland, thinks about materials research policy.

During the $1980 \mathrm{~s}$, much attention was focused on comparing the United States to Europe and Japan and predicting how the United States would fare in an increasingly competitive global marketplace. It became clear that future technologies, and consequently, future competitiveness, depended in part on advances made in materials.

To understand where the United States stood in materials, the National Research Council (NRC) commissioned a major review of materials science and engineering in the mid-1980s. Its final report identified materials synthesis and processing as weak links in U.S. materials research and development. "[Those two areas] covered a broad slice of materials [in general]," said Adriaan DeGraaf of the Division of Materials Research at the National Science Foundation (NSF).

The NRC recommendation spurred the Bush administration to propose advanced materials and processing as one of several R\&D initiatives for the fiscal year 1992 federal budget. As with earlier so-called crosscutting programs on global change and high performance computing, this proposal put materials high on the federal agenda. "It focused attention on materials in a very positive way," DeGraaf said. "It had a very positive effect on support."

Yet even the committee formed as a result of that initiative "was an extension of work going on a long time," Schwartz said. Under Schwartz's leadership, this committee pulled together the first crosscutting analysis of the various activities of U.S. agencies in materials work. For the previous two years, it has issued surveys of federal activity in materials science which included what agencies were doing and with how much money. At the same time, its members had begun to identify infrastructure and construction, automotive, aeronautics, and electronics as four key priorities and to set up subcommittees to develop policy for them.

However, no one could agree on the proper relationship between government and the private sector. Partisan politics inhibited the setting up of priorities and the planning about what to do next, Schwartz said.

The arrival of the Clinton administration remedied that, as now the President and the congressional majority agreed government had a role to play in technology development, Schwartz said. This new President abolished the Federal Coordinating Council for Science, Engineering and Technology (FCCSET) and the materials initiative with it. In its place, he created the National Science and Technology Council (NSCT). That Council took a look at all U.S. research and development, Schwartz said. One of the nine committees subsequently set up is the civilian industrial technology committee. It includes three topical subcommittees, each one responsible for automotive, electronics, or construction and building R\&D. Three more subcommittees deal with areas that cut across these three topics, covering manufacturing infrastructure, materials technology, and environmental technologies.

The materials technology subcommittee of the NSCT replaces the old FCCSET materials group and has continued that committee's work, Schwartz said. Members of each agency that sponsors some materials work belong to this subcommittee and its working groups.

"Materials is no longer highlighted as a separate activity but is... dispersed under many activities," DeGraaf said. Both he and Schwartz agree that much progress has been made in developing and supporting a coherent science and technology policy for materials, one that seems to be working. "You don't hear anymore about the U.S. lagging behind," said DeGraaf.

But this new Congress does leave even Washington policy veterans wondering about the continued growth in support for materials science. "Throughout the years, I think the outcome [for materials research] has been quite good," DeGraaf said. "There are different priorities now. [In my areas] how materials will come out of that will depend on how NSF comes out. I am cautiously optimistic, but I simply don't know."

In the meantime, Schwartz's subcommittee on materials technology has worked with the private sector to create "road maps" of materials research goals for those inside and outside the invisible boundary. Also, by fall, that subcommittee expects to publish a recently completed updated survey of federal activity in materials science.

ELIZABETH PENNISI

\section{NRC Report Highlights Hierarchical Structures}

The Committee on Synthetic Hierarchical Structures issued a National Research Council (NRC) report in December 1994 identifying numerous aspects of natural materials that could be mimicked to design new classes of synthetic materials. The committee focused on structural materials systems and their properties. Hierarchical structures are assemblages of molecular units or their aggregates embedded or intertwined with other phases, which in turn are similarly organized at increasing size levels. Currently, the employment of many synthetic hierarchical materials is limited by the availability of fabrication technology. The committee, therefore, recommends the application of biological hierarchical design concepts to materials development in areas of adhesives, composites, low-friction and wear-resistant materials for joints and bearings, and synthetic constituents to produce hierarchical materials with useful performance in various environmental conditions.

The scientific opportunities discussed in the report include improvements in the fracture toughness of current composites, durable adhesives in the formation and strength of composites in wet environments, and interfacing soft and hard materials. Biological cells placed within synthetic materials can be studied to both advance biomaterial technologies and add insight for structuring hard materials, and to design self-assembling synthetic materials, according to the report.

Among technical opportunities, the committee discusses biomedical materials such as synthetic grafts and the development of gels; improved membranes; smart materials applications such as failure sensing and repair, and shape memory; synthetic functionally graded materials; and the development of "smart" composites.

The committee further recommended that the materials community prepare for the future development of integrated systems design and performance by imple menting appropriate educational and engineering programs.

The report, Hierarchical Structures in Biology as a Guide for New Materials Technology, can be obtained by calling 800-624-6242. $\square$ 